\title{
Epigenetic Diet to Modulate Immune Response against SARS-CoV-2
}

\author{
Andika $^{1 *}$, Risa Ahdyani ${ }^{1}$, Linda Erlina ${ }^{2}$, Azminah $^{3}$, Arry Yanuar $^{4}$ \\ ${ }^{1}$ Faculty of Pharmacy, Universitas Muhammadiyah Banjarmasin, South Kalimantan, Indonesia \\ ${ }^{2}$ Faculty of Medicine, Universitas Indonesia, Jakarta, Indonesia \\ ${ }^{3}$ Faculty of Pharmacy, Universitas Surabaya, Surabaya, East Java, Indonesia \\ ${ }^{4}$ Faculty of Pharmacy, Universitas Indonesia, Depok, West Java, Indonesia
}

ARTICLE HISTORY

Received: June 2020

Revised: July 2020

Accepted : August 2020

\begin{abstract}
The COVID-19 pandemic has spread to various parts of the world and caused many deaths. The victims are infected by SARS-CoV-2, a new type of coronavirus that has appeared since December 2019 and caused respiratory symptoms, fever, coughing, and shortness of breath. In addition to social distancing, wearing masks and washing hands, diet is important as a defense of the body against SARS-CoV-2. In this review, researchers conducted epigenetic diet studies that could potentially inhibit SARS-CoV-2, and can be consumed and used on a daily basis.
\end{abstract}

Keywords: SARS-CoV-2; COVID-19; epigenetics; epigenetics diet

*corresponding author

Email: andika@umbjm.ac.id

\section{INTRODUCTION}

It was reported that Coronavirus $(\mathrm{CoV})$ has caused fatal pneumonic plague in humans since its emergence in the early 21 st century. Severe acute respiratory syndrome coronavirus (SARS-CoV) infected five continents in 2003 which caused mortality by $10 \%$ of the total victims worldwide (Cheng, Lau, Woo, \& Kwok, 2007) (Lee et al., 2003). The Middle East Respiratory Syndrome Coronavirus (MERS-CoV) also caused an epidemic disease in the Arabian Peninsula in 2012 with a mortality rate of $35 \%$ (Zaki, Van Boheemen, Bestebroer, Osterhaus, \& Fouchier, 2012) (de Groot et al., 2013). It is found that the victims of both SARS-CoV and MERS$\mathrm{CoV}$ are infected by animals (Zhu et al., 2020). Since the Wuhan pneumonia virus case was discovered in December 2019, the coronavirus was then named as the 2019 novel coronavirus or "2019-nCoV" by the World Health Organization (WHO) on January 12, 2020 (Zhu et al., 2020). Because the 2019-nCoV is very identical with SARS-CoV, the International Committee on Virus Taxonomy (ICVT) has categorized the 2019-nCoV as severe acute respiratory syndrome coronavirus 2 (SARSCoV-2) on 11 February 2020, while the disease caused by $2019-\mathrm{nCoV}$ was named COVID-19 by WHO. There has been no specific medicine or vaccine suitable for the treatment of this disease yet (Y. Chen, Liu, \& Guo, 2020) (Huang et al., 2020).

The COVID-19 outbreak has spread to many countries across the globe. WHO reported on June 8, 2020 that a total of $6,881,352$ victims were confirmed from 216 countries. More than 399,895 (5,811\%) people died. In Indonesia, from the data announced by Gugus Tugas
Percepatan Penanganan COVID-19, it was recorded that the number of infected people was 31,186 and 1,851 people died per June 7, 2020 (covid19.go.id).

Actions that must be taken to minimize the risk of contracting COVID-19 according to WHO recommendations are frequent hand washing, keeping a minimum distance of 1 (one) meter, avoiding touching eyes, nose and mouth, wearing masks, avoiding crowded places and staying at home (WHO, 2020). Furthermore, appropriate dietary supplements, another additional treatment may be needed to decrease or prevent the widespread effects of the virus as well as to increase the body immune of humans.

Diet is one of the important factors in the epigenetic issue. Several studies have shown that the epigenetic diet has the potential to prevent disease and improve overall health. Epigenetic refers to regulation of gene expression and chromatin modification with no alterations in the DNA sequence that modulate changes of cellular phenotypes (Carlos-Reyes et al., 2019). Epigenetic mechanism of gene expression is complex, including DNA methylation, histone modification, and non-coding RNA. These pathways are usually activated during viral infection (Adhya \& Basu, 2010).

Bioactive substances as a result of an epigenetic diet can be included in a personal regular diet and can be used for medicinal or chemopreventive purposes (Hardy \& Tollefsbol, 2011). It has been reported that a diet rich in certain fruits and vegetables could modify epigenomes that lead to stronger body's defense against viruses (Hardy \& Tollefsbol, 2011). 
Table 1. Division of epigenetic classes (Andreoli, Jorge, Barbosa, Parenti, \& Rio, 2013)

\begin{tabular}{llll}
\hline No & Enzyme & Type of Action & Mechanism of Action \\
\hline 1 & Methyltransferase & DNA Methylation & DNA Methylation \\
2 & Deacetylase & Deacetylation & Histone Modification \\
3 & Acetyl Transferase & Acetylation & \\
4 & Mono-ADP-ribosyl transferase & ADP-ribosylation & \\
5 & Poly-ADP-ribosyl transferase & ADP-ribosylation & \\
6 & Biotin-ligase/ biotinidase & Biotinylation & \\
7 & Deiminase & Citrullination & \\
8 & Glycosyltransferase/ Glycosidase & Glycosylation & \\
9 & K and R methyltransferase & Methylation & \\
10 & Demethylase & Methylation & \\
11 & Kinase/ Phosphatase & Phosphorylation & \\
12 & Enzyme E1, E2, and E3 & Ubiquitylation & Non-coding RNA \\
13 & miRNA regulating protein & microRNA expression & \\
\hline
\end{tabular}

There are several natural compounds found in dietary phytochemical that can affect human epigenome, such as quercetin, luteolin, herperitin, hesperidin, EGCG (epigallocatechin-3-gallate), resveratrol, thymoquinone, curcumin, and selenium. These natural compounds may act through epigenetic mechanism such as DNA methylation, histone modification, and non-coding. In this review, we first present an overview of the epigenetic classes and mechanism then we summarize epigenetic diets through natural phytochemical compounds that are represented as potential agents to inhibit SARS-CoV-2.

\section{Epigenetics}

Epigenetics is the study of inherited gene changes which do not cause changes in the structure of the genome, as the changes in phenotype that involve the changes in genotype are in response to environmental stimuli. Epigenetic mechanisms may occur in: (a) The methylation of DNA in vertebrates which is commonly the result of the addition of methyl groups to cytosine whereas cytosine and guanine exist in the same DNA structure, (b) Modification of histones, the addition or removal of a chemical group to a core protein around a damaged DNA, and (c) non-coding RNA such as microRNAs (miRNAs), which unify mRNA to control the revealed code of gene in the post-transcription (Weaver, 2014) early life experience, nutrition, medication, infection. DNA and RNA methylation mechanism are the main biological processes in epigenetics (Table 1).

\section{Methylation mechanism and its relation with COVID-19}

Genomics modification of RNAvirus through methylation has a significant impact on the replication, assembly, and maturation of the virus. An example of this is the 5'cap of RNA virus produced by methylation in the position of $\mathrm{N}^{7}$-guanosine and 2'-O-adenosine. The presence of $\mathrm{N}^{6}$-methyladenosine $\left(\mathrm{m}^{6} \mathrm{~A}\right)$ is explained through mRNA in several ssRNAs. Moreover, some enzyme or protein are produced by the host and are inhabited by the virus in fusion, and cells replication are highly possible for activation or deactivation by modification in the DNA methylation (Williams, Gokhale, \& Horner, 2019) (Wu et al., 2019).

When SARS-CoV-2 breaks into host cells, the virus needs ongoing transcription of cells for the production of mRNA. This mechanism indicates a functionally linked relation with the expression of the host genome, therefore it triggers the infected cells to confront the host cell for every replicated pathogen produced. The main task is that RNA viruses can take the DNA methyltransferases (DNMTs) for the methylation process and reduce some particular functions of genes, such as the innateness and adaptive characteristics of human body immune responses (Marcos-Villar et al., 2018).

Based on research conducted by Corley Nhdlovu and Pinto in 2020, it was stated that the methylation pattern plays an important role in encoding the angiotensin-converting enzyme 2 (ACE2) gene that acts as the SARS$\mathrm{CoV}-2$ virus receptor in human lung epithelial cells. Findings indicate that the estimation of production of the ACE2 enzyme can be predicted based on the epigenetic modulation process of a gene (Corley \& Ndhlovu, 2020) (Pinto et al., 2020). 
Binding sites for inhibiting virus infection in the cell Several enzymes/proteins from the host or virus can inhibit or reduce viral infections, such as:

1) ACE2 receptor

ACE2 receptor function is for binding SARS-CoV-2 to cells. This interaction has been identified at the atomic level and could be the target for small molecule.

2) Spike protein

Spike protein can be used as a medium for viral binding and cell insertion through receptor-binding domains (RBD). Based on structural analysis, identified residues in the SARS-CoV-2 RBD are essential for ACE2 binding.

\section{3) Furin protease and TMPRSS2}

The $\mathrm{S}$ protein in SARS-CoV-2 contains putative furin recognition motif (PRRARSV) and transmembrane serine protease 2 (TMPRSS2) which functions are to prime protein and undertake cell membrane fusion. Particularly, the furin site in the SARS-CoV-2 S1 / S2 binding is special and important for the division of highly efficient $\mathrm{S}$ proteins and is an important determinant in virus transmission and pathogenicity.

4) Replicase complex

Replicase complex includes 3-chymotrypsin-like protease (3CLpro), Papain like protease (PLpro), helicase, and RNA-dependent RNA polymerase (RdRP), which serves to replicate the virus after entering the cell.

5) DNA Methyltransferases (DNMTs)

DNA methyltransferases serve for DNA methylation to control gene function. The reduction of DNMT may reactivate the function of immune-related genes that have functions to combat viral infections.

6) RNA Methyltransferases

RNA methyltransferases include enzymes such as METTL3/14 which can maintain the workflow of RdRP and mRNA cap guanine-N7-methyltransferase which help maintaining the ability of the virus to replicate. (Hoffmann et al., 2020) (Belouzard, Millet, Licitra, \& Whittaker, 2012) (Walls et al., 2020) (Coutard et al., 2020).

\section{Epigenetic control with the epigenetic diet}

Certain foods such as fruits contain abundant bioactive compounds and can modify epigenomes that lead to better health improvements including the protection of the body's immune system from viruses (Hardy $\&$ Tollefsbol, 2011). To protect the body from SARS$\mathrm{CoV}-2$, the consumed fruits should contain sufficient and varied nutrients to protect body from the virus (Erlund et al., 2002). Based on these principles and other scientific literatures, the following compounds have been examined and can potentially help in reducing the side effects of SARS-CoV-2 virus infection: quercetin, luteolin, hesperetin, hesperidin, EGCG (epigallocatechin-3gallate), resveratrol, thymoquinone, curcumin, and selenium.

\section{Quercetin}<smiles>O=c1c(O)c(-c2ccc(O)c(O)c2)oc2cc(O)cc(O)c12</smiles>

Figure 1. Structure of quercetin

Quercetin is a flavonoid compound contained in oranges, green leafy vegetables, buckwheat, peanuts, a variety of flowers, bark, broccoli, olive oil, apples, onions, green tea, red wine, cherries, blueberries, and cranberries. Vegetables such as onions and broccoli, fruits such as apples, cherries, and berries, and drinks such as tea and red wine are rich in flavonols (Anand David, Arulmoli, \& Parasuraman, 2016).

The potentially produced enzymes/proteins by quercetin are ACE2, 3CLpro, and helicase. Molecular forming shows a good amalgamation between quercetin and this protein. The study found that quercetin can be used to treat SARS virus effectively (Nguyen et al., 2012). Research conducted by Park and colleagues states that quercetin are able to inhibit protease SARS-CoV (3CLpro and PLpro) and Middle Eastern Respiratory Syndrome coronavirus (MERS-CoV) 3CLpro protease in vitro with $\mathrm{IC}_{50}$ values of 52.7, 8.6, and $34.8 \mu \mathrm{M}$, respectively (Park et al., 2017). Another study also conducted by Ryu and colleagues stated that quercetin has an inhibitory activity against 3CLpro with an $\mathrm{IC}_{50}$ value of $23.8 \mu \mathrm{M}$ (Ryu et al., 2010).

\section{Luteolin, Hesperetin, Hesperidin}

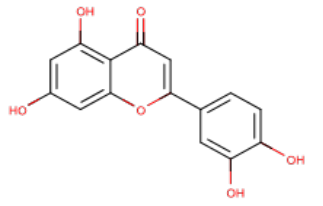

(a)<smiles>O=C1C[C@@H](c2ccc(O)c(O)c2)Oc2cc(Cl)cc(Cl)c21</smiles>

(b)

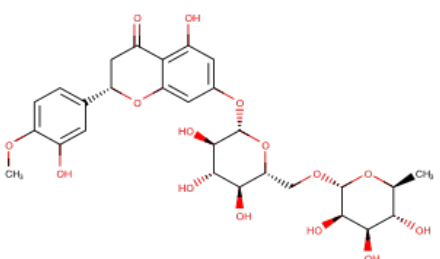

(c)

Figure 2. Structure of (a) luteolin; (b) hesperetin; (c) heseperidin 
Luteolin (3,4,5,7-tetrahydroxy flavone) is a natural flavonoid produced by many plant species. Several vegetables, such as celery, chrysanthemum, paprika, carrots, leeks, broccoli, and parsley are rich in luteolin (Anand David et al., 2016). Luteolin is also contained in oranges and juniper fruit. Research conducted by Ryu and colleagues stated that luteolin has inhibitory activity against 3CLpro with an $\mathrm{IC}_{50}$ value of $20.2 \mu \mathrm{M}$ (Ryu et al., 2010).

Based on the previous study conducted by Lalani \& Poh (2020), luteolin is a natural biomolecule that acts as a potential antiviral agent against DNA and RNA viruses. The inhibition of severe acute respiratory syndrome coronavirus (SARS-CoV) occurs through mechanism of binding to the $\mathrm{S} 2$ protein of the virus.

Hesperetin is a bioflavonoid compound that is abundant in Citrus aurantium and Citri reticulatae pericarpium. The $\mathrm{IC}_{50}$ of hesperetin in inhibiting the cleavage activity of 3C-like proteases (3CLpro) from SARS-coronavirus using cell-based assay is $8.3 \mu \mathrm{M}$ (C.-W. Lin et al., 2005). The docking results of hesperetin against ACE2 enzyme showed that hesperetin has the potential to bind to ACE2 with Gibbs binding free energy of $-8.3 \mathrm{kcal} \mathrm{mol}^{-1}$ by binding to the sides of TYR-613, SER-611, ARG-482, and GLU-479 (H. Chen \& Du, 2020).

Hesperidin is known as a flavanone glycoside, commonly found in citrus fruits such as lemons, sweet oranges (Citrus sinensis), sour oranges, Ponderosa lemons, and Citrus unshiu (Garg, Garg, Zaneveld, \& Singla, 2001). A study conducted by Utamo and colleagues (2020) shows that hesperidin, one of the compounds in Citrus $s p$., has the lowest level of docking rate compared with other three protein receptors, although it has a high affinity value for receptor binding. On the other hand, curcumin, brazilin, and galangin have been proven to have good affinities for receptors, which means that these ingredients may become effective inhibitors of viruses. In general, based on molecular docking studies, it can be concluded that hesperidin is highly potential to be used as an inhibitor for SARS-CoV-2, along with galangin, brazilin, and curcumin with Gibbs binding free energy values of $-13.51,-12.96,-12.36$, and $-11.82 \mathrm{kcal} \mathrm{mol}^{-1}$, respectively. Molecular docking of hesperidin was also carried out by Chen and colleagues by using AutoDock Vina and Gibss binding free energy value of $-10.1 \mathrm{kcal}$ $\mathrm{mol}^{-1}$ was obtained (Y. W. Chen, Yiu, \& Wong, 2020). Molecular docking studies reveal that these compounds can be well compounded with ACE2, furin, 3CLpro, and $\mathrm{S}$ protein viruses (Utomo, Ikawati, \& Meiyanto, 2020) (H. Chen \& Du, 2020) (Yi et al., 2004).

\section{EGCG (epigallocatechin-3-gallate)}<smiles>O=C(O[C@H]1Cc2c(O)cc(O)cc2O[C@@H]1c1cc(O)c(O)c(O)c1)c1cc(O)c(O)c(O)c1</smiles>

Figure 3. Structure of EGCG

EGCG (epigallocatechin-3-gallate) is a specific flavanol derivative, flavan-3-ol. EGCG can be found in green tea and is well known for its effectiveness as an antioxidant for cancer prevention. Green tea is non-fermented, freshly dried tea leaves. In Asian culture, green tea is widely believed to have efficacy in preventing and curing various diseases. Recent biological and pharmacological activity studies show that green tea has antioxidant activity, including cardiovascular, antimutagenic, antiviral and anti-cancer protection with epigenetic methylation modulation, histone modification and miRNA (Du et al., 2012) (Pointner et al., 2017). A molecular docking study shows that DNA methyltransferases (DNMTs), ACE2, and helicase may interact well with EGCG (Jo, Kim, Shin, \& Kim, 2020). Another molecular docking study conducted by Khan and colleagues states that EGCG has a stronger binding affinity value than remdesivir and chloroquine (Khan, Khan, Khan, Ahamad, \& Ansari, 2020).

\section{Resveratrol}

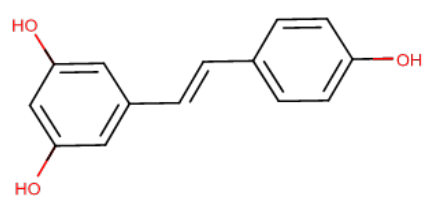

Figure 4. Structure of resveratrol

Resveratrol is a group of polyphenols that are naturally produced by peanuts, mulberries, cranberries, blueberries, and grape skins. Red wines are also the natural sources of Resveratrol (Das, Mukherjee, \& Ray, 2010). Resveratrol significantly inhibits MERS-CoV infection and prolongs the life of cells that have been infected with the virus, and decreases apoptosis induced by MERS-CoV in vitro (Lin et al., 2017). Remarkably, Resveratrol is a natural compound that affects epigenetic mechanism, and it is especially related to some enzymes 
such as DNA methyltransferase (DNMT) and histone deacetylase (HDAC). These enzymes regulate the mechanism of action through DNA methylation and histone modification (Fernandes, Silva, Pavan, Chiba, Chin, \& Santos, 2017).

\section{Thymoquinone}<smiles>CC1=CC(=O)C(C(C)C)=CC1=O</smiles>

\section{Figure 5. Structure of thymoquinone}

Nigella sativa (black seed) is a worldwidely wellknown herb that has been used for curing various body impairment, illnesses, respiratory system disorder, digestive tract problem, kidneys issue, liver disease, and cardiovascular malfunction and immune systems problem. Nigella sativa contains several active compounds such as thymoquinone (30-48\%), thymohydroquinone, dithymoquinone, p-cymene (7$15 \%)$, carvacrol (6-12\%), 4-terpineol (2-7\%), and t-anethol (1-4\%).

Thymoquinone (TQ) has been proven to work more effectively by epigenetic mechanisms (El-Dakhakhny, 1963) (Haslberger, Jacob, Hippe, \& Karlic, 2020). Thymoquinone has been described to activate the Nrf2 transcription factor. Its activation results in cells protection against viral infection associated with oxidative stress and inflammation reduction. Nfr2 may also reduce the expression of angiotensin-converting enzyme 2 (ACE2) receptor in respiratory epithelial cells that works as a receptor for coronavirus. Consequently, the activation of $\mathrm{Nfr} 2$ transcription could be a potential target to prevent and manage SARS-CoV-2 infection (Mendonca \& Soliman, 2020).

\section{Curcumin}

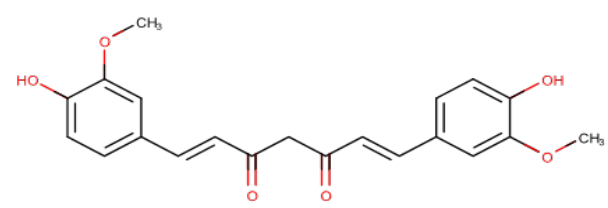

Figure 6. Structure of curcumin

Curcumin, or also known as diferuloylmethane, is a polyphenol substance from Curcuma longa. Curcumin is the essential element in turmeric and it produces curry yellow color. People in India and China use curcumin as anti-inflammatory, antioxidant, antiangiogenic, and anticancer as well as a herbal therapy (Aggarwal, Kumar, \& Bharti, 2003) (Goel \& Aggarwal, 2010). Curcumin has antiviral and antibacterial effects against influenza viruses, hepatitis C, HIV, and strains of Staphylococcus, Streptococcus, and Pseudomonas. This antiviral activity can be observed in different targets such as hepatitis, influenza, arbovirus viruses, members of Zika virus (ZIKV), and chikungunya virus (CHIKV) (Praditya et al., 2019) (Anggakusuma et al., 2014) (Barthelemy et al., 1998).

\section{Selenium (Se)}

The quality of selenium in grains and vegetables relies on the quality of the soil. Particular vegetables such as turnips, peas, beans, carrots, tomatoes, beets, potatoes, and cucumbers may contain a maximum of $6 \mathrm{mg} \mathrm{g}^{-1}$ selenium whereas other vegetables such as onions and asparagus may contain up to $17 \mu \mathrm{g} \mathrm{g}^{-1}$ selenium when harvested from the land containing lots of selenium. Garlic and brassica (cabbage, broccoli, mustard) are other sources which are rich in selenium. Compared to vegetables, fruits contain a lower percentage of selenium, with only several fruits contain selenium of up to $10 \mu \mathrm{g} \mathrm{kg}^{-1}$. For instance, Brazil nuts contain high proteins and rich in selenium (Roman, Jitaru, \& Barbante, 2014) (Mehdi, Hornick, Istasse, \& Dufrasne, 2013). Selenium (Se) is an essential substance to control redox reaction. It can become an antioxidant if combined with selenocysteine and selenoproteins (Guillin, Vindry, Ohlmann, \& Chavatte, 2019). Se deficiency causes an increase in reactive oxygen species (ROS) and oxidative stress that inhibit the response of immune system to the virus and an increase in the mutation rate of the RNA virus. The increasing rate of the virus mutation and the decrease in the immunity may increase the virulence (Polansky \& Lori, 2020).

A study conducted by Zhang and colleagues reported that people from the regions which have land rich in selenium were highly possible to recover faster from the virus, based on provinces with more than 200 cases and cities with more than 40 cases. In Enshi city, Hubei Province, which selenium concentration is the highest in China, the recovery rate was almost three times higher than that of the other cities in Hubei Province. In contrast, in Heilongjiang Province, which land contains the lowest percentage of selenium in the world, the mortality rate from COVID-19 was almost five times higher than that of other provinces outside Hubei (Zhang, Taylor, Bennett, Saad, \& Rayman, 2020).

\section{Amount of Food Intake for Consumption}

Based on current research and findings, the recommended food intake (Table 2) as a supplement in the proper dosage can help people protect themselves from viral disease and 
Table 2. Bioactive compounds of the epigenetic diet, natural source and the amount of daily intake required for defense against viruses

\begin{tabular}{|c|c|c|c|}
\hline Compound & Natural source & $\begin{array}{l}\text { Daily intake } \\
\text { recommendation }\end{array}$ & Literature \\
\hline Quercetin & $\begin{array}{l}\text { Garlic, chieves, } \\
\text { flower/ fruit capers, } \\
\text { black tea, apple }\end{array}$ & $50-800 \mathrm{mg}$ & $\begin{array}{l}\text { (Justesen, Knuthsen, Andersen, \& Leth, 2000) } \\
\text { (Haslberger et al., 2020) }\end{array}$ \\
\hline Luteolin & Red paprika, celery & $150 \mathrm{mg}$ & (Erlund et al., 2002) \\
\hline Hesperetin & Orange, orange juice & $132 \mathrm{mg}$ & (Dong et al., 2014) \\
\hline Hesperidin & Lemon, lime & $100-126 \mathrm{mg}$ & $\begin{array}{l}\text { (Justesen et al., 2000) } \\
\text { (Khan et al., 2020) }\end{array}$ \\
\hline EGCG & Green tea, black tea & $225-800 \mathrm{mg}$ & $\begin{array}{l}\text { (Boschmann \& Thielecke, 2007) (Institute for } \\
\text { Functional Medicine, 2020)(La Porte et al., } \\
\text { 2010) }\end{array}$ \\
\hline Resveratrol & $\begin{array}{l}\text { Grape, mulberry, } \\
\text { blueberry }\end{array}$ & $500-2000 \mathrm{mg}$ & $\begin{array}{l}\text { (Haslberger et al., 2020) } \\
\text { (Khan et al., 2020) }\end{array}$ \\
\hline Thymoquinone & $\begin{array}{l}\text { Black cumin, black } \\
\text { cumin oil }\end{array}$ & Up until $500 \mathrm{mg}$ & (Khan et al., 2020) \\
\hline Curcumin & Turmeric, curry & $500 \mathrm{mg}$ & $\begin{array}{l}\text { (Jayawardena, Sooriyaarachchi, Chourdakis, } \\
\text { Jeewandara, \& Ranasinghe, 2020) }\end{array}$ \\
\hline Selenium & $\begin{array}{l}\text { Brazil nut, broccoli, } \\
\text { carrot }\end{array}$ & $50-100 \mu \mathrm{g}$ & (Kipp et al., 2015) \\
\hline
\end{tabular}

control COVID-19 infection by suppressing the spread and pathogenesis of SARS-CoV-2. Compounds such as quercetin, luteolin, hesperetin, hesperidin, EGCG, resveratrol, thymoquinone, curcumin, and selenium can become a primary inhibitor for SARS-CoV-2. Close attention and scrutiny analysis may help in finding the promising molecules that can be consumed to slow down the widespread of coronavirus. This food intake can be useful as a suggestion for the diet of patients and health workers of COVID-19 in controlling and avoiding the infections. Diet can also prevent secondary infections because these compounds have previously been proven to contain antimicrobial substances (Erlund et al., 2002) (Haslberger et al., 2020) (Khan et al., 2020).

\section{CONCLUSION}

From the main focus of this review, quercetin, EGCG, luteolin, hesperetin, hesperidin, curcumin, resveratrol, thymoquinone, and selenium could be potential inhibitors for the activity of SARS-CoV-2 that causes COVID-19 and these natural products can be gained from fruits and vegetables that are usually consumed on daily basis.

\section{REFERENCES}

Aggarwal, B. B., Kumar, A., \& Bharti, A. C. (2003). Anticancer potential of curcumin: preclinical and clinical studies. Anticancer Research, 23(1A), 363398. Retrieved from http://www.ncbi.nlm.nih.gov/ pubmed/12680238

Anand David, A. V., Arulmoli, R., \& Parasuraman, S. (2016). Overviews of biological importance of quercetin: A bioactive flavonoid. Pharmacognosy Reviews, 10(20), 84-89. https://doi.org/10.4103/0973-7847.194044

Andreoli, F., Jorge, A., Barbosa, M., Parenti, M. D., \& Rio, A. Del. (2013). Modulation of Epigenetic Targets for Anticancer Therapy : Clinicopathological Relevance, Structural Data and Drug Discovery Perspectives. Current Pharmaceutical Design, 19, 578-613.

Anggakusuma, Colpitts, C. C., Schang, L. M., Rachmawati, H., Frentzen, A., Pfaender, S., Steinmann, E. (2014). Turmeric curcumin inhibits entry of all hepatitis C virus genotypes into human liver cells. Gut, 63(7), 1137-1149. https://doi.org/10.1136/gutjnl-2012-304299

Baglivo, M., Baronio, M., Natalini, G., Beccari, T., Chiurazzi, P., Fulcheri, E., Bertelli, M. (2020). Natural small molecules as inhibitors of coronavirus lipid-dependent attachment to host cells: A possible strategy for reducing SARS-COV-2 infectivity? Acta Biomedica, 91(1), 161-164. https://doi.org/10.23750/ abm.v91i1.9402 
Barthelemy, S., Vergnes, L., Moynier, M., Guyot, D., Labidalle, S., \& Bahraoui, E. (1998). Curcumin and curcumin derivatives inhibit Tat-mediated transactivation of type 1 human immunodeficiency virus long terminal repeat. Research in Virology, 149(1), 43-52. https://doi. org/10.1016/S0923-2516(97)86899-9

Belouzard, S., Millet, J. K., Licitra, B. N., \& Whittaker, G. R. (2012). Mechanisms of coronavirus cell entry mediated by the viral spike protein. Viruses, 4(6), 10111033. https://doi.org/10.3390/v4061011

Boschmann, M., \& Thielecke, F. (2007). The effects of epigallocatechin-3-gallate on thermogenesis and fat oxidation in obese men: A pilot study. Journal of the American College of Nutrition, 26(4), 389S-395S. https://doi.org/10.1080/07315724.2007.10719627

Carlos-Reyes, A., Lopez-Gonzalez, J.S., MenesesFlores, M., Gallardo-Rincon, D., Ruiz-Garcia, E., Marchat, L.A., ...Lopez-Camarillo, C. (2019). Dietary compounds as epigenetic modulating agents in cancer. Frontiers in Genetics, 10(MAR), 1-14. https://doi.org/ 10.3389/fgene.2019.00079.

Chen, H., \& Du, Q. (2020). Potential natural compounds for preventing SARS-CoV-2 (2019-nCoV) infection. Preprints, 2(January), 2020010358. https://doi. org/10.20944/preprints202001.0358.v3

Chen, Y., Liu, Q., \& Guo, D. (2020). Emerging coronaviruses: Genome structure, replication, and pathogenesis. Journal of Medical Virology, 92(4), 418423. https://doi.org/10.1002/jmv.25681

Chen, Y. W., Yiu, C.-P. B., \& Wong, K.-Y. (2020). Prediction of the SARS-CoV-2 (2019-nCoV) 3C-like protease (3CLpro) structure: virtual screening reveals velpatasvir, ledipasvir, and other drug repurposing candidates. F1000Research, 9, 129. https://doi. org/10.12688/f1000research.22457.1

Cheng, V. C. C., Lau, S. K. P., Woo, P. C. Y., \& Kwok, Y. Y. (2007). Severe acute respiratory syndrome coronavirus as an agent of emerging and reemerging infection. Clinical Microbiology Reviews, 20(4), 660694. https://doi.org/10.1128/CMR.00023-07

Corley, M., \& Ndhlovu, L. (2020). DNA Methylation Analysis of the COVID-19 host cell receptor, Angiotensin I Converting Enzyme 2 gene (ACE2) in the Respiratory System Reveal Age and Gender Differences. Medicine and Pharmacology, (March, 19), 1-29. https:// doi.org/10.20944/preprints201810.0478.v1
Coutard, B., Valle, C., de Lamballerie, X., Canard, B., Seidah, N. G., \& Decroly, E. (2020). The spike glycoprotein of the new coronavirus 2019-nCoV contains a furin-like cleavage site absent in $\mathrm{CoV}$ of the same clade. Antiviral Research, 176(January), 104742. https://doi.org/10.1016/j.antiviral.2020.104742

Das, D. K., Mukherjee, S., \& Ray, D. (2010). Resveratrol and red wine, healthy heart and longevity. Heart Failure Reviews, 15(5), 467-477. https://doi.org/10.1007/ s10741-010-9163-9

de Groot, R. J., Baker, S. C., Baric, R. S., Brown, C. S., Drosten, C., Enjuanes, L., ... Ziebuhr, J. (2013). Middle East Respiratory Syndrome Coronavirus (MERS-CoV): Announcement of the Coronavirus Study Group. Journal of Virology, 87(14), 7790-7792. https://doi.org/10.1128/ jvi.01244-13

Dong, W., Wei, X., Zhang, F., Hao, J., Huang, F., Zhang, C., \& Liang, W. (2014). A dual character of flavonoids in influenza A virus replication and spread through modulating cell-autonomous immunity by MAPK signaling pathways. Scientific Reports, 4, 1-12. https:// doi.org/10.1038/srep07237

Du, G., Zhang, Z., Wen, X., Yu, C., Calway, T., Yuan, C., \& Wang, C. (2012). Epigallocatechin Gallate (EGCG) Is the Most Effective Cancer Chemopreventive Polyphenol in Green Tea. Nutrients, 4(12), 1679-1691. https://doi. org/10.3390/nu4111679

El-Dakhakhny, M. (1963). Studies on the chemical constitution of egyptian Nigella sativa 1 . Seeds. Ii 1 ) the essential oil. Planta Medica, 11(04), 465-470. https:// doi.org/10.1055/s-0028-1100266

Erlund, I., Silaste, M. L., Alfthan, G., Rantala, M., Kesäniemi, Y. A., \& Aro, A. (2002). Plasma concentrations of the flavonoids hesperetin, naringenin and quercetin in human subjects following their habitual diets, and diets high or low in fruit and vegetables. European Journal of Clinical Nutrition, 56(9), 891-898. https://doi.org/10.1038/sj.ejcn.1601409

Garg, A., Garg, S., Zaneveld, L. J. D., \& Singla, A. K. (2001). Chemistry and pharmacology of the Citrus bioflavonoid hesperidin. Phytotherapy Research, 15(8), 655-669. https://doi.org/10.1002/ptr.1074

Goel, A., \& Aggarwal, B. B. (2010). Curcumin, the golden spice from Indian saffron, is a chemosensitizer and radiosensitizer for tumors and chemoprotector and radioprotector for normal organs. Nutrition and Cancer, 62(7), 919-930. https://doi.org/10.1080/01635581.2010 .509835 
Guillin, O. M., Vindry, C., Ohlmann, T., \& Chavatte, L. (2019). Selenium, Selenoproteins and Viral Infection. Nutrients, 11(9), 2101. https://doi.org/10.3390/ nu11092101

Hardy, T. M., \& Tollefsbol, T. O. (2011). Epigenetic diet: Impact on the epigenome and cancer. Epigenomics, 3(4), 503-518. https://doi.org/10.2217/epi.11.71

Haslberger, A., Jacob, U., Hippe, B., \& Karlic, H. (2020). Mechanisms of selected functional foods against viral infections with a view on COVID-19: Mini review. Functional Foods in Health and Disease, 10(5), 195. https://doi.org/10.31989/ffhd.v10i5.707

Hoffmann, M., Kleine-Weber, H., Schroeder, S., Krüger, N., Herrler, T., Erichsen, S., ... Bae, Y. (2020). SARSCoV-2 Cell Entry Depends on ACE2 and TMPRSS2 and Is Blocked by a Clinically Proven Protease Inhibitor. Cell, 21(1), 1-10. https://doi.org/10.1016/j.cell.2020.02.052

Huang, C., Wang, Y., Li, X., Ren, L., Zhao, J., Hu, Y., ... Cao, B. (2020). Clinical features of patients infected with 2019 novel coronavirus in Wuhan, China. The Lancet, 395(10223), 497-506. https://doi.org/10.1016/ S0140-6736(20)30183-5

Institute for Functional Medicine. (2020). COVID-19 Nutraceutical-and-Botanical-Recommendations-forPatients_v4. Retrieved from https://p.widencdn.net/ kvdwlh/COVID-19_Nutraceutical-and-BotanicalRecommendations-for-Patients_v4

Jayawardena, R., Sooriyaarachchi, P., Chourdakis, M., Jeewandara, C., \& Ranasinghe, P. (2020). Enhancing immunity in viral infections, with special emphasis on COVID-19: A review. Diabetes \& Metabolic Syndrome: Clinical Research \& Reviews, 14(4), 367-382. https:// doi.org/10.1016/j.dsx.2020.04.015

Jo, S., Kim, S., Shin, D. H., \& Kim, M. S. (2020). Inhibition of SARS-CoV 3CL protease by flavonoids. Journal of Enzyme Inhibition and Medicinal Chemistry, 35(1), 145-151. https://doi.org/10.1080/14756366.2019 .1690480

Justesen, U., Knuthsen, P., Andersen, N. L., \& Leth, T. (2000). Estimation of daily intake distribution of flavonols and flavanones in Denmark. Scandinavian Journal of Nutrition/Naringsforskning, 44(4), 158-160. https://doi.org/10.3402/fnr.v44i0.1781

Khan, M. F., Khan, M. A., Khan, Z. A., Ahamad, T., \& Ansari, W. A. (2020). Identification of Dietary Molecules as Therapeutic Agents to Combat COVID-19 Using Molecular Docking Studies. Research Square, 1-17. https://doi.org/10.21203/rs.3.rs-19560/v1

Kipp, A. P., Strohm, D., Brigelius-Flohé, R., Schomburg, L., Bechthold, A., Leschik-Bonnet, E., \& Heseker, H. (2015). Revised reference values for selenium intake. Journal of Trace Elements in Medicine and Biology, 32, 195-199. https://doi.org/10.1016/j.jtemb.2015.07.005

La Porte, C., Voduc, N., Zhang, G., Seguin, I., Tardiff, D., Singhal, N., \& Cameron, D. W. (2010). Steadystate pharmacokinetics and tolerability of transresveratrol $2000 \mathrm{mg}$ twice daily with food, quercetin and alcohol (Ethanol) in healthy human subjects. Clinical Pharmacokinetics, 49(7), 449-454. https://doi. org/10.2165/11531820-000000000-00000

Lee, N., Hui, D., Wu, A., Chan, P., Cameron, P., Joynt, G. M., ... Sung, J. J. Y. (2003). A Major Outbreak of Severe Acute Respiratory Syndrome in Hong Kong. New England Journal of Medicine, 348(20), 1986-1994. https://doi.org/10.1056/NEJMoa030685

Lin, S. C., Ho, C. T., Chuo, W. H., Li, S., Wang, T. T., \& Lin, C. C. (2017). Effective inhibition of MERS$\mathrm{CoV}$ infection by resveratrol. BMC Infectious Diseases, 17(1), 1-10. https://doi.org/10.1186/s12879-017-2253-8

Marcos-Villar, L., Díaz-Colunga, J., Sandoval, J., Zamarreño, N., Landeras-Bueno, S., Esteller, M., ... Nieto, A. (2018). Epigenetic control of influenza virus: Role of H3K79 methylation in interferon-induced antiviral response. Scientific Reports, 8(1), 1-13. https:// doi.org/10.1038/s41598-018-19370-6

Mehdi, Y., Hornick, J. L., Istasse, L., \& Dufrasne, I. (2013). Selenium in the environment, metabolism and involvement in body functions. Molecules, 18(3), 32923311. https://doi.org/10.3390/molecules 18033292

Nguyen, T. T. H., Woo, H. J., Kang, H. K., Nguyen, V. D., Kim, Y. M., Kim, D. W., ... Kim, D. (2012). Flavonoidmediated inhibition of SARS coronavirus 3C-like protease expressed in Pichia pastoris. Biotechnology Letters, 34(5), 831-838. https://doi.org/10.1007/s10529011-0845-8

Park, J. Y., Yuk, H. J., Ryu, H. W., Lim, S. H., Kim, K. S., Park, K. H., ... Lee, W. S. (2017). Evaluation of polyphenols from Broussonetia papyrifera as coronavirus protease inhibitors. Journal of Enzyme Inhibition and Medicinal Chemistry, 32(1), 504-512. https://doi.org/1 $0.1080 / 14756366.2016 .1265519$

Pinto, B. G., Oliveira, A. E., Singh, Y., Jimenez, L., Goncalves, A. N., Ogava, R. L., ... Nakaya, H. I. (2020). ACE2 Expression is Increased in the Lungs of 
Patients with Comorbidities Associated with Severe COVID-19. MedRxiv, 2020.03.21.20040261. https://doi. org/10.1101/2020.03.21.20040261

Pointner, A., Magnet, U., Tomeva, E., Dum, E., Bruckmueller, C., Mayer, C., \& Haslberger, A. (2017). EGCG Containing Combined Dietary Supplement Affects Telomeres and Epigenetic Regulation. Journal of Nutrition \& Food Sciences, 07(01), 1-10. https://doi. org/10.4172/2155-9600.1000577

Polansky, H., \& Lori, G. (2020). Coronavirus disease 2019 (COVID-19): first indication of efficacy of Gene-EdenVIR/Novirin in SARS-CoV-2 infection. International Journal of Antimicrobial Agents, (January), 105971. https://doi.org/10.1016/j.ijantimicag.2020.105971

Praditya, D., Kirchhoff, L., Brüning, J., Rachmawati, H., Steinmann, J., \& Steinmann, E. (2019). Anti-infective properties of the golden spice curcumin. Frontiers in Microbiology, 10(MAY), 1-16. https://doi.org/10.3389/ fmicb.2019.00912

Pruimboom, L. (2020). Methylation Pathways and SARS-CoV-2 Lung Infiltration and Cell MembraneVirus Fusion Are Both Subject to Epigenetics. Frontiers in Cellular and Infection Microbiology, 10(May), 1-5. https://doi.org/10.3389/fcimb.2020.00290

Roman, M., Jitaru, P., \& Barbante, C. (2014). Selenium biochemistry and its role for human health. Metallomics, 6(1), 25-54. https://doi.org/10.1039/c3mt00185g

Ryu, Y. B., Jeong, H. J., Kim, J. H., Kim, Y. M., Park, J. Y., Kim, D., ... Lee, W. S. (2010). Biflavonoids from Torreya nucifera displaying SARS-CoV 3CLpro inhibition. Bioorganic and Medicinal Chemistry, 18(22), 7940-7947. https://doi.org/10.1016/j.bmc.2010.09.035

Utomo, R. Y., Ikawati, M., \& Meiyanto, E. (2020). Revealing the Potency of Citrus and Galangal Constituents to Halt SARS-CoV-2 Infection. Preprints. Org, 2(March), 1-8. https://doi.org/10.20944/ preprints202003.0214.v1

Walls, A. C., Park, Y.-J., Tortorici, M. A., Wall, A., McGuire, A. T., \& Veesler, D. (2020). Structure, Function, and Antigenicity of the SARS-CoV-2 Spike Glycoprotein. Cell, 181(2), 281-292.e6. https://doi. org/10.1016/j.cell.2020.02.058
Weaver, I. C. G. (2014). Integrating early life experience, gene expression, brain development, and emergent phenotypes: Unraveling the thread of nature via nurture. Advances in Genetics (Vol. 86). Elsevier. https://doi. org/10.1016/B978-0-12-800222-3.00011-5

WHO. (2020). Advice for public. Retrieved from https://www.who.int/emergencies/diseases/novelcoronavirus-2019/advice-for-public

Williams, G. D., Gokhale, N. S., \& Horner, S. M. (2019). Regulation of Viral Infection by the RNA Modification N6 -Methyladenosine . Annual Review of Virology, $6(1), \quad 235-253 . \quad$ https://doi.org/10.1146/annurevvirology-092818-015559

Wu, F., Cheng, W., Zhao, F., Tang, M., Diao, Y., \& Xu, R. (2019). Association of N6-methyladenosine with viruses and related diseases. Virology Journal, 16(1), 1-10. https://doi.org/10.1186/s12985-019-1236-3

Yi, L., Li, Z., Yuan, K., Qu, X., Chen, J., Wang, G., ... $\mathrm{Xu}, \mathrm{X}$. (2004). Small Molecules Blocking the Entry of Severe Acute Respiratory Syndrome Coronavirus into Host Cells. Journal of Virology, 78(20), 11334-11339. https://doi.org/10.1128/jvi.78.20.11334-11339.2004

Zaki, A. M., Van Boheemen, S., Bestebroer, T. M., Osterhaus, A. D. M. E., \& Fouchier, R. A. M. (2012). Isolation of a novel coronavirus from a man with pneumonia in Saudi Arabia. New England Journal of Medicine, 367(19), 1814-1820. https://doi.org/10.1056/ NEJMoa1211721

Zhang, J., Taylor, E. W., Bennett, K., Saad, R., \& Rayman, M. P. (2020). Association between regional selenium status and reported outcome of COVID-19 cases in China. The American Journal of Clinical Nutrition. Oxford University Press. https://doi.org/10.1093/ajen/ nqaa095

Zhu, N., Zhang, D., Wang, W., Li, X., Yang, B., Song, J., ... Tan, W. (2020). A novel coronavirus from patients with pneumonia in China, 2019. New England Journal of Medicine, 382(8), 727-733. https://doi.org/10.1056/ NEJMoa2001017 